\title{
Application of Activated Afzelia Africana and Acacia Albida Carbon for Removal of Pollutants in Textile Wastewater
}

\author{
Femi K. Owofadeju ${ }^{1}$, Temitayo A. Ewemoje ${ }^{2}$, Victor O. Fatokun ${ }^{3}$, Temidayo A. Okedele ${ }^{4}$ \\ ${ }^{1}$ Department of Wood Products Engineering, University of Ibadan, Nigeria \\ ${ }^{2,3}$ Department of Agricultural and Environmental Engineering, University of Ibadan, Nigeria \\ ${ }^{4}$ National Environmental Standards and Regulations Enforcement Agency, Ibadan, Nigeria
}

\begin{abstract}
Adsorption of contaminants in textile wastewater onto activated carbon derived from two wood species has been studied using batch-adsorption techniques. This study was carried out to examine the removal efficiency of the low-cost adsorbent (Afzelia africana) AFA and (Acacia albida) ACA for the removal of heavy metals and other organic contaminants from textile effluents. The influence of contact time and adsorbent dose kept constant on the adsorption process was also studied. Removal efficiency increased with increase in contact time. The two adsorbents had an average removal efficiency of $60 \%$ at $90 \mathrm{mins}$ contact time for $\mathrm{Zn}$. The ACA had higher removal efficiency for chromium at all contact times than AFA except at 120mins contact time where there existed a slight difference in the removal efficiency between the two adsorbents. Removal efficiency of iron was high between 58.18- 70.52\% and 72.75-75.86\% for AFA and ACA carbon respectively. This showed that iron had high affinity to the adsorbents surface. It was observed that AFA exhibited highest removal efficiency for nitrate at all contact times as compared to ACA. Results indicated that the freely abundant, locally available, low-cost adsorbent derived from the two wood species could be treated as being economically viable for the removal of contaminants from textile effluents.
\end{abstract}

KEYWORDS: Adsorption, Contaminants, Environment, Effluent, Heavy Metals, Pollution

\section{INTRODUCTION}

The release of hazardous contaminants into the environment through industrial wastewater and related sources and their removal methods are of global concern.[1] Pollutants found in wastewater pose health hazards to both flora and fauna if their concentrations exceed the standard permissible limits.[2] Most of these waste contain suspended solids, dissolved solids, nitrate, phosphate, biochemical oxygen demand, chemical oxygen demand, phosphate, salt and heavy metals, which are nevertheless required by living organism in a small concentration.[3] However, in higher concentration, these minerals can cause critical human and environmental health problems.[4] Thus, the treatment of these contaminants and heavy metals in wastewaters before being discharging into the ecosystem is essential.[5]

Textile industries are among the industries that discharge effluents containing heavy metals and contaminants into the environment. The textile industry has been one of the main contributors to water pollution all over the world, causing more than $20 \%$ of the registered levels of water pollution in countries like Turkey, Indonesia and China (among the G20 group of countries) and also in Romania and Bulgaria (in the Eastern European area), with even more than 44\% in Macedonia.[6] Dyeing is an important aspect of textile production, and during the dyeing processes, not all dyes that are applied to the fabrics are fixed on them. There is always a portion of these dyes that remains unfixed to the fabrics and gets washed out. These unfixed dyes are found to be in high concentrations in textile effluents and contribute significantly to the pollution of the wastewater. [7]

In Nigeria, Abeokuta is known for the production of Adire and Kampala, a business that provides substantial contribution to its economy in the form of income, employment and possibly foreign exchange generation. Wastewater from the industry has negatively impacted surface, shallow wells and ground water in the region as well as the freshwater bodies in the vicinity of the production site. The water pollution results in deterioration of water quality and making it harmful for human consumption. Oloyede et al. [8] reported that 'Adire' textile effluents had a deleterious effect upon the weight, blood profile, lungs, kidney, spleen and heart of mice, which could lead to many metabolic and physiological disorders. Thus, treatment of wastewater from textile industry is pertinent in order to minimize their threat to the biotic community. 


\section{International Journal of Current Science Research and Review}

ISSN: 2581-8341

Volume 04 Issue 12 December 2021

DOI: 10.47191/ijesrr/V4-i12-26, Impact Factor: 5.825

IJCSRR@ 2021

WWw.ijesrr.org

Adsorption has been universally accepted by the world environmentalists for the disposal of hazardous and toxic inorganic as well as organic pollutants present in various effluents. [1] Investigation of readily available and low cost sorbent with high removal capability has been performed in various studies.[4] This present work aimed to assess the adsorptive capability of activated carbon derived from two readily abundant low density wood species on textile wastewater.

Margins, column widths, line spacing, and type styles are built-in; examples of the type styles are provided throughout this document and are identified in italic type, within parentheses, following the example. Please do not re-adjust the margins.

\section{MATERIALS AND METHODS}

\section{Study area description.}

The study area Abeokuta $76^{\prime} \mathrm{N}$ to $7^{\circ} 13^{\prime} \mathrm{N}$ and $316^{\prime} \mathrm{E}$ to $3^{\circ} 25^{\prime} \mathrm{E}$ is a millennium city and the state headquarters of Ogun State, with its environ having an area coverage of about $781.16 \mathrm{~km} 2$.[9] Tie and dye have been produced in Itoku, Abeokuta South Local Government for over a century. The clothing comes in different designs and batiks as popularly called with diverse variety of colours and these products have gained international recognition. The textile industry in Itoku is one major textile industry whose processes are not maintained at regulatory standards. Large volume of water are involved in the process and their effluents are discharged into the surrounding nearby watercourses and on land without evidence of pre-treatment. Textile wastewater was therefore sourced from this area to determine its physico-chemical parameters and the viability of activated carbon derived from two low density woods (Afzelia africana and Acacia albida) in detoxifying the contaminants.

\section{Samples preparation.}

The wood feedstock (Afzelia africana and Acacia albida) were sourced and chipped into smaller pieces at Oke-Ado Sawmill in Ibadan, Oyo State, and thereafter washed with deionised water to remove waste particles adhered onto the surface. The wood samples were air-dried for moisture reduction for a period of one week. The feedstock were pyrolysed at $500^{\circ} \mathrm{C}$ for 2 hours in a bioreactor. The charred woods were grinded and activated with zinc chloride at ration 1:1 (w/v). To ensure proper impregnation, the samples were properly mixed manually and kept for 24 hours and subjected to temperature at $102 \pm 3^{\circ} \mathrm{C}$ for 24 hours. Thereafter, filtrates (char) were washed and dried repeatedly with distilled water to neutralize the $\mathrm{pH}$, oven-dried at $120^{\circ} \mathrm{C}$ for 12 hours and cooled at room temperature before storage. Scanning Electron Microscope (SEM, TESCAN VEGA3: was used to examine the pore space of the sorbents.

The carbonization yield was determined using equation 1

$$
\text { Percentage yield }=\frac{W 2}{W 1} \times 100 \text {. }
$$

$\mathrm{W}_{2}=$ Weight of carbon produced

$\mathrm{W}_{1}=$ Weight of raw sample

\section{Analytical methods.}

Wastewater samples used in the adsorption experiment were analysed according to APHA (1999) standard methods for water and wastewater examination. Adsorption studies was conducted by batch method on wastewater at room temperature by varying contact time. Batch experiments were carried out to determine the adsorption of contaminants onto the adsorbents in $200 \mathrm{~mL}$ flask. Continuous mixing was provided by intermittent agitation of the samples to allow interfacial contact. The effects of various parameters on the rate of adsorption process were observed by varying contact time at an interval of 30minutes to $120 \mathrm{minutes}$ at room temperature. The adsorbent volume $(V)$ was kept constant at $6 \mathrm{~g}$. The experiments were conducted in duplicates for each of experimental carbon to cater for possible variations. The percentage removal was calculated using equation 2

$$
\text { Percentage removal }=\frac{(C i-C e)}{C i} \times 100 \text {. }
$$

Where,

$\mathrm{Ci}(\mathrm{mg} / \mathrm{L})$ represents initial concentration of effluents before process of adsorption

$\mathrm{Ce}(\mathrm{mg} / \mathrm{L})$ represents residual concentration after adsorption of effluents 


\section{International Journal of Current Science Research and Review}

ISSN: 2581-8341

Volume 04 Issue 12 December 2021

DOI: 10.47191/ijcsrr/V4-i12-26, Impact Factor: 5.825

IJCSRR@ 2021

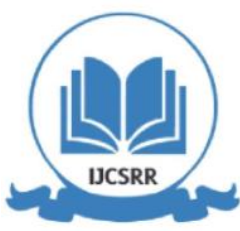

Www.ijcsrr.org

\section{RESULTS AND DISCUSSION}

\section{Activated carbon characterization.}

The carbon yields after carbonisation at a temperature of $500^{\circ} \mathrm{C}$ for 120 minutes were 32 and $24 \%$ respectively. The result agreed with previous study carried out at the same temperature for oak tree branch $(28.6 \%) .{ }^{[10]}$ and Cordia millenii $(24.5 \%) .{ }^{[11]}$ Scanning Electron Microscope images of the two adsorbents used AFA and ACA samples showed presence of several pore spaces in the adsorbents (Figs 1a and b). This will facilitate easier trapping of impurities when used in the treatment of textile effluent. On observation, the circumference sizes of the pore spaces varied for the two adsorbents, with AFA having more pores than ACA and this is partly responsible for their differential behaviour in adsorption process. Also, the shape of the pore spaces was predominantly spherical for both samples with surface having rough structure. This structure also shows that the material will be a very good adsorbent theoretically. ${ }^{[12-14]}$
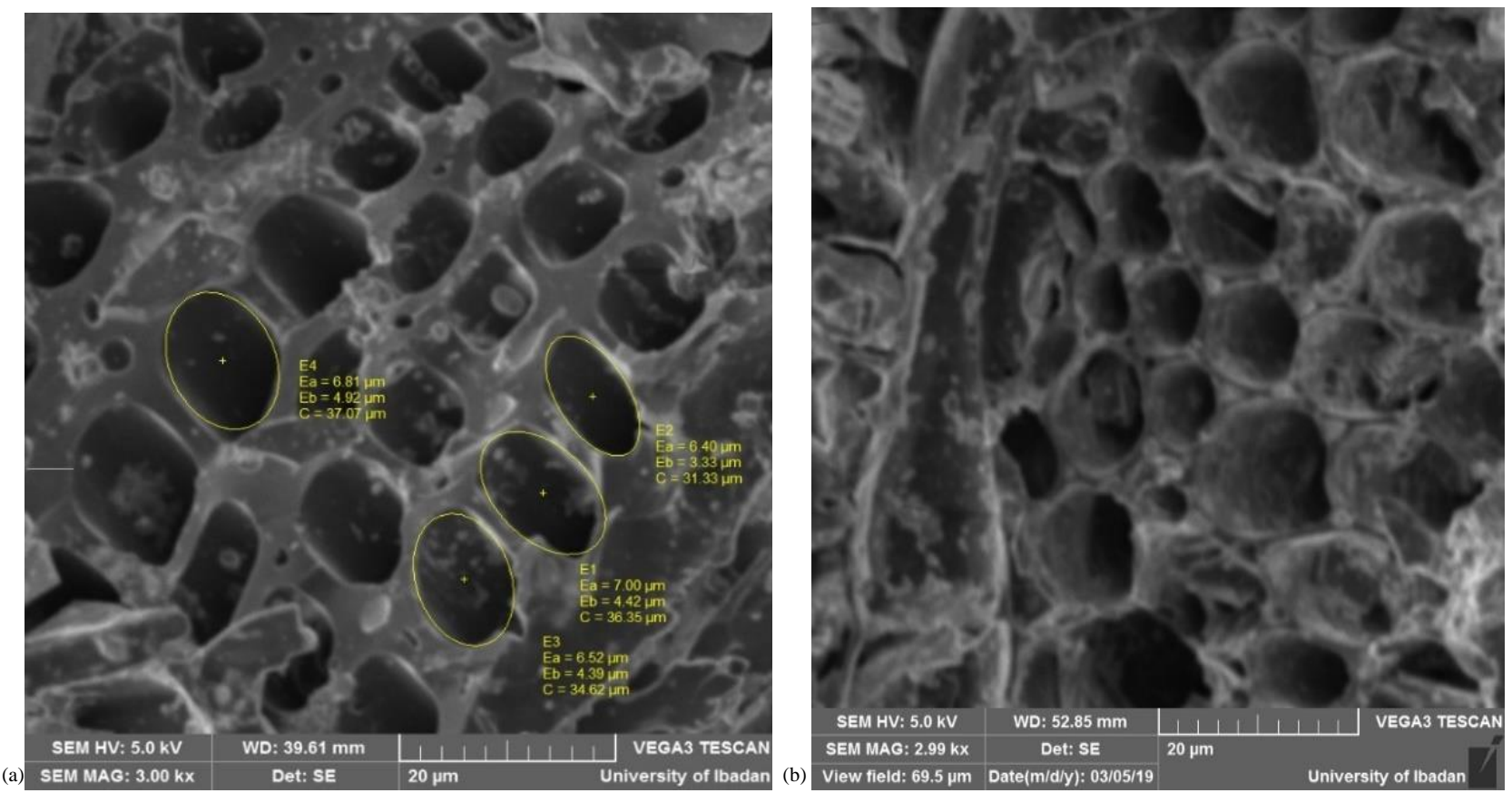

Fig. 1. Electron micrograph of adsorbent: a- Alcacia albida carbon b- Afzelia africana carbon

\section{Removal efficiency of heavy metal.}

The removal efficiency of all the heavy metals treated increased with contact time. From Figure 2, there was rapid uptake of $74 \%$ percentage removal efficiency for Manganese $(\mathrm{Mn})$ at 30mins contact time using ACA carbon whereas percentage removal of Mn using AFA carbon was low (between 30.7-48.4\%), showing that ACA is more effective in removing Mn, the finding is in agreement with the result of locust beans husk ${ }^{[15]}$ and Cordia millenii Carbon and Gmelina arborea Carbon. ${ }^{[14]}$

The AFA has the highest removal efficiency (59.72-77.78\%) for Cadmium from at all contact time. The two adsorbents had removal efficiency of over $60 \%$ at $90 \mathrm{mins}$ contact time for Zinc. ACA has higher removal efficiency for chromium at all contact time than AFA except at 120mins contact time where there exists a slight difference in the removal efficiency between the two adsorbents. Removal efficiency was high in iron between 58.18- 70.52\% and 72.75-75.86\% for AFA and ACA carbon respectively. This shows that iron has high mobility to the adsorbents surface. 


\section{International Journal of Current Science Research and Review}

ISSN: 2581-8341

Volume 04 Issue 12 December 2021

DOI: 10.47191/ijesrr/V4-i12-26, Impact Factor: 5.825

IJCSRR@ 2021

www.ijesrr.org

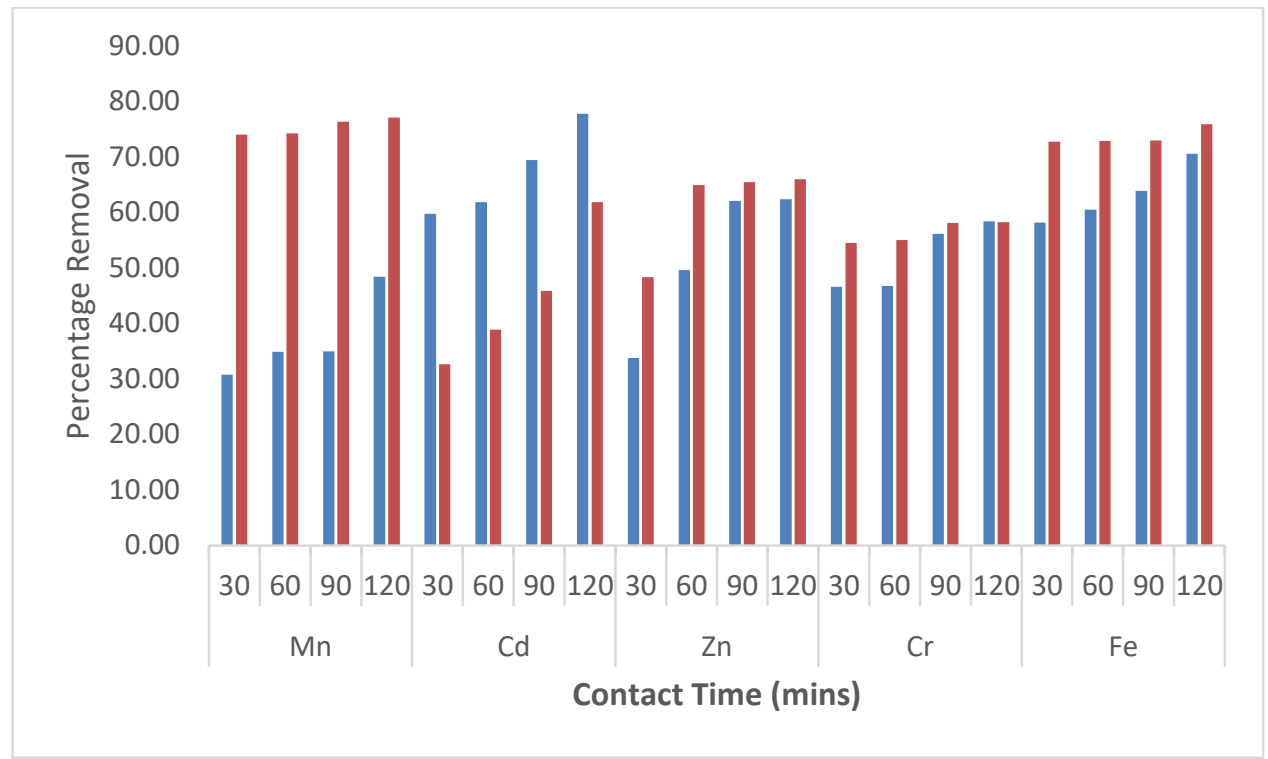

Fig. 2. Graph of decontamination level (in percent) using the two adsorbents

\section{Decontamination of organic pollutants.}

Figures 3 and 4 show the effect of different contact time of AFA and ACA carbon on the percentage removal of sulphate, nitrate and phosphate. The percentage removal increased from $22.4-31.08 \%$ for sulphate, $69.42-75.83 \%$ for nitrate, $48.85-55.19 \%$ for phosphate for AFA carbon and that of ACA carbon increased from 14.32- $29.73 \%$ for sulphate, $53.72-57.64 \%$ for nitrate and 24.78 $37.75 \%$ for phosphate respectively. It was observed that AFA exhibited highest removal efficiency for nitrate at all contact time as compared to ACA. Similar result was obtained for phosphate which can be attributed to strong interaction between AFA adsorbents and the contaminants (nitrate and phosphate). The result also showed that sulphate requires higher contact time and dosage of adsorbent for it removal by adsorption process. This is in conformity with the result obtained by de Caprariis et al. ${ }^{[16]}$. Both carbon show less affinity for sulphate. The result of the treatment showed that the diminution of the contaminants increased with increasing contact time and the trend at which each of the adsorbents adsorbed the contaminants is as a function of their microstructure.

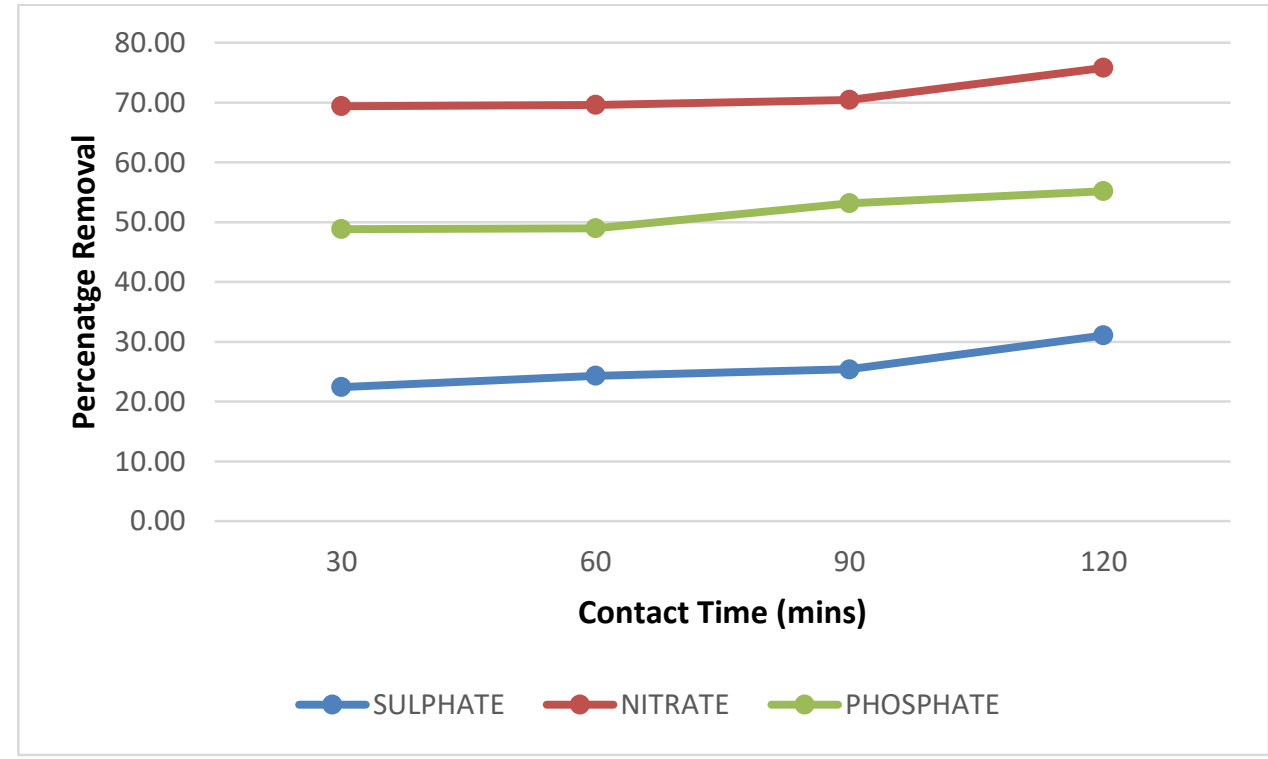

Fig. 3. Effect of AFA on percentage removal of sulphate, nitrate and phosphate 


\section{International Journal of Current Science Research and Review}

ISSN: 2581-8341

Volume 04 Issue 12 December 2021

DOI: 10.47191/ijcsrr/V4-i12-26, Impact Factor: 5.825

IJCSRR@ 2021

www.ijesrr.org

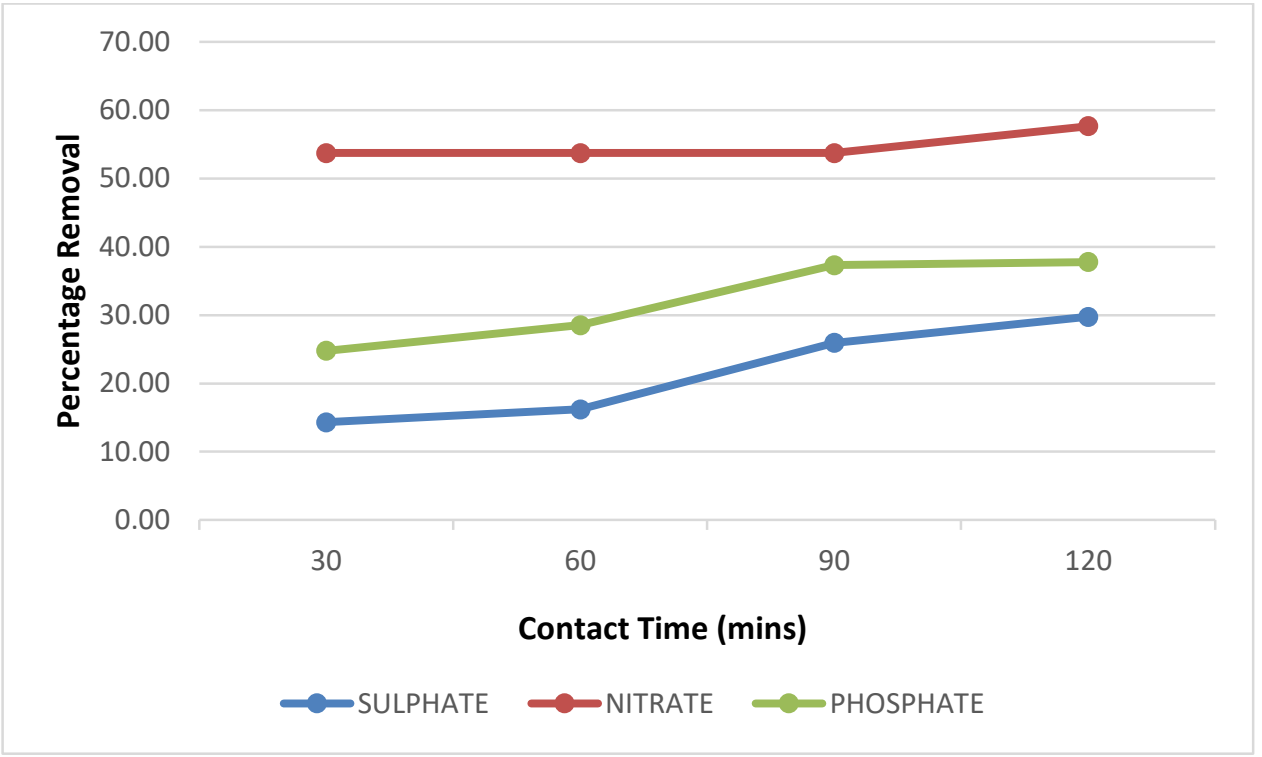

Fig. 4. Effect of ACA on percentage removal of sulphate, nitrate and phosphate

\section{CONCLUSION}

Activated carbons produced from low density woods (Afzelia africana and Acacia albida) were tested on the adsorption of textile wastewater. The study revealed that contact time and pore space of the adsorbents influenced the removal of the contaminants from the wastewater. The ACA was more effective in removal of heavy metal except for cadmium as compared to AFA, on the other hand, AFA performed better in removal of inorganic pollutants in textile wastewater. Among all the heavy metal studied, iron showed high mobility to the surface for the two adsorbents. The activated carbons derived from the two-wood species were able to reduce the contaminants in the textile wastewater and proved to be effective in reducing the parameters below specified limit set by WHO for discharge of industrial wastewater onto land and surface water bodies.

\section{REFERENCES}

1. Mittal, A.; Teotia, M.; Soni, R.K. and Mittal, J. 2016. Applications of egg shell and egg shell membrane as adsorbents: A Review, Journal of Molecular Liquids. doi: 10.1016/j.molliq.2016.08.065

2. Okafor, J.O.; Agbajelola, D.O.; Peter, S.; Adamu, M and David, G.T. 2015. Studies on the adsorption of heavy metals in a paint industry effluent using activated maize cob. Journal of Multidisciplinary Engineering Science and Technology (JMEST). 2, 39-46.

3. Sapci, Z. and Ustun, E.B. 2012. Interactions between contaminated aquatic environments and element uptake by Echinodorus amazinocus and Cryptocoryne undulata. Ecotoxicol. Environ. Saf. 76, 114-125.

4. Pathirana, C.; Ziyath, A.M.; Jinadasa, K.; Egodawatta, P.; Sarina, S.; Goonetilleke, A. 2019. Quantifying the influence of surface physico-chemical properties of biosorbents on heavy metal adsorption. Chemosphere, 234, 488-495

5. Sapci-Ayas, Z. 2021. Investigation of direct applicability of modified agricultural waste for contaminant removal from real textile wastewater. Water. $13,1354$.

6. Paraschiv, D.; Tudor, C. and Petrariu, R. 2015. The textile industry and sustainable development: A Holt-Winters Forecasting Investigation for the Eastern European Area.

Sustainability. 7, 1280-1291

7. Hassaan, M. A. and El Nemr, A. 2017. Advanced oxidation processes for textile wastewater treatment. International Journal of Photochemistry and Photobiology. 2, 85-93.

8. Oloyede, A.M.; Ogunlaja, O. and Ogunlaja, A. 2014. Sub-chronic toxicity assessment of local textile 'Adire and Kampala' (Tie and Dye) effluents on mice (Mus musculus). Research Journal of Environmental Sciences. 8, 142-148. 


\section{International Journal of Current Science Research and Review}

ISSN: 2581-8341

Volume 04 Issue 12 December 2021

DOI: 10.47191/ijesrr/V4-i12-26, Impact Factor: 5.825

IJCSRR@ 2021

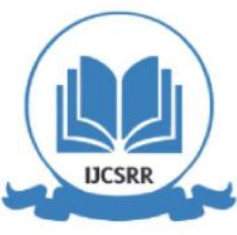

www.ijesrr.org

9. Baloye, D. O.; and Palamuleni, L. G. 2016. Modelling a critical infrastructure-driven spatial database for proactive disaster management: A developing country context. Jamba (Potchefstroom, South Africa). 8, 220.

10. Jindo, K.; Mizumoto, H.; Sawada, Y.; Sanchez-Monedero, M. A. and Sonoki, T. 2014. Physical and chemical characterization of biochars derived from different agricultural residues. Bio-geosciences. 11, 6613-6621.

11. Fatokun, V.O.; Owofadeju, F. K.; Ewemoje, O.E. and Ewemoje, T.A. 2021. Batch Adsorption investigation of the use of Cordia milleni carbon for wastewater treatment. Journal of Applied Science and Environmental Management (JASEM). 25, 949-953.

12. Ijaola, O.O.; Ogedengbe, K. and Sangodoyin, A.Y. 2013. Kinetic study of water contaminants adsorption by bamboo granular activated and Non-activated carbon. International Journal of Engineering and Technology Innovation. 3, 289-298

13. Omotoso, O.A. and Sangodoyin, A.Y. 2013. Production and utilization of cassava peel activated carbon in treatment of effluent from cassava processing industry. Water Practice \& Technology. 8, 215-224

14. Fatokun, V.O.; Owofadeju, F.K.; Ewemoje, O.E. and Ewemoje, T.A. 2021. Investigation of adsorbent characteristics of carbonized low-density woods in the treatment of textile effluent. FUOYE Journal of Engineering and Technology (FUOYEJET). 6, 1-4.

15. Ajayi-Banji, A.A.; Ewemoje, T.A. and Ajimo, A.A. 2015. Efficacy of locust beans husk char in heavy metal sequestration. Environ. Res. Eng. and Mgt. 71, 5-10.

16. de Caprariis, B.; Paolo De F.; Elisabetta P. and Marco S. 2018. Activated biochars used as adsorbents for dyes removal. Chemical Engineering Transactions. 64, 22-28

Cite this Article: Femi K. Owofadeju, Temitayo A. Ewemoje, Victor O. Fatokun, Temidayo A. Okedele (2021). Application of Activated Afzelia Africana and Acacia Albida Carbon for Removal of Pollutants in Textile Wastewater. International Journal of Current Science Research and Review, 4(12), 1809-1814 